\title{
Growth and nutrient accumulation in mycorrhized papaya seedlings cultivated in a phosphorus-fertilized substrate
}

\author{
Dácio Jerônimo de Almeida ${ }^{1}$, Walter Esfrain Pereira ${ }^{2 *}$, Patrícia da Silva Alexandre ${ }^{3}$, \\ Járisson Cavalcante Nunes ${ }^{4}$, Wagner de Melo Ferreira ${ }^{5}$
}

10.1590/0034-737X201663010012

\begin{abstract}
The indiscriminate use of mineral fertilizers in papaya orchards has increased production costs, and the use of arbuscular mycorrhizal fungi is a promising alternative to reduce such expenses. Therefore, the present research aimed at studying the efficiency of arbuscular mycorrhizal fungi (AMF) on dry matter and nutrient accumulation in Sunrise Solo papaya seedlings, by applying doses of $\mathrm{P}_{2} \mathrm{O}_{5}$ (triple superphosphate) that are harmful to the symbiosis. The experiment was carried out in a protected environment and was set up in a randomized block design with four replications, and consisted of four $\mathrm{P}_{2} \mathrm{O}_{5}$ doses $\left(0,672,1386\right.$ and $\left.2100 \mathrm{mg} \mathrm{dm}^{-3}\right)$, three mycorrhizal fungi species (Gigaspora margarita, Entrophospora colombiana and Scutellospora heterogama) and the control treatment (mycorrhiza-free). Shoot and root dry matter as well as nitrogen, phosphorus and potassium contents in leaf and root tissues were assessed. Mycorrhizal inoculation promoted a 30\% increase in shoot dry matter in relation to the control treatment. Mycorrhizal fungi promoted increases in leaf and root nitrogen content up to $672 \mathrm{mg} \mathrm{dm}^{-3} \mathrm{P}_{2} \mathrm{O}_{5}$. Inoculation of E. colombiana favored the highest gains in root and shoot dry matter. $\mathrm{P}_{2} \mathrm{O}_{5}$ fertilization increased foliar and root phosphorus content.
\end{abstract}

Key words: Carica papaya, mycorrhizae, triple superphosphate.

\section{RESUMO}

\section{Crescimento e acúmulo de nutrientes em mudas micorrizadas de mamoeiro em substrato adubado com fósforo}

O uso indiscriminado de fertilizantes minerais na cultura do mamoeiro tem elevado os custos de produção, sendo o uso de fungos micorrízicos arbusculares uma alternativa promissora para diminuir os custos. Esta pesquisa teve como objetivo avaliar a eficiência dos fungos micorrízicos arbusculares (FMA), no acúmulo de massa da matéria seca e de nutrientes, em mudas de mamoeiro Sunrise Solo, perante a aplicação de doses de superfosfato triplo, consideradas prejudiciais à simbiose. $\mathrm{O}$ experimento foi conduzido em ambiente protegido, no delineamento em blocos casualizados, com quatro repetições, no esquema $4 \times 3+1$ : quatro doses $\left(0,0 ; 672 ; 1386\right.$ e $\left.2100 \mathrm{mg} \mathrm{dm}^{-3}\right)$ de $_{2} \mathrm{O}_{5}$ (superfosfato triplo), três espécies de fungos micorrízicos: Gigaspora margarita, Entrophospora colombiana e Scutellospora heterogama e o tratamento controle (sem inoculação e sem $\mathrm{P}_{2} \mathrm{O}_{5}$ ). Foram quantificadas as massas das matérias secas das partes aérea e radicular, além dos teores de nitrogênio, fósforo e potássio dos tecidos vegetais (folha e raiz). A inoculação com fungos micorrízicos aumentou em $30 \%$ a massa da matéria seca da parte aérea, em comparação com a do tratamento controle. Os fungos micorrízicos aumentaram os teores foliar e radicular de nitrogênio até a dose de $672 \mathrm{mg} \mathrm{dm}^{-3} \mathrm{de}$

\footnotetext{
Submitted on 04/06/2015 and approved on 10/26/2015.

${ }^{1}$ Universidade Federal da Paraíba, Departamento Solos e Engenharia Rural, Areia, Paraíba, Brasil. almeida_dacio@hotmail.com

${ }^{2}$ Universidade Federal da Paraíba, Departamento Ciências Fundamentais e Sociais, Areia, Paraíba, Brasil. walterufpb@yahoo.com.b

Universidade Federal da Paraíba, Departamento de Solos e Engenharia Rural, Areia, Paraíba, Brasil. patriciareia@yahoo.com.br

${ }^{4}$ Universidade Federal da Paraíba, Departamento de Solos e Engenharia Rural, Areia, Paraíba, Brasil. jarissonagro@hotmail.com

${ }^{5}$ Universidade Federal do Tocantins, Núcleo de Estudos Ambientais, Porto Nacional, Tocantins, Brasil. wmelouft@yahoo.com

Corresponding author: walterufpb@yahoo.com.br
} 
$\mathrm{P}_{2} \mathrm{O}_{5}$. A inoculação do fungo Entrophospora colombiana promoveu maiores ganhos de biomassa. A adubação com $\mathrm{P}_{2} \mathrm{O}_{5}$ aumentou os teores de fósforo foliar e radicular.

Palavras-chaves: Carica papaya, micorrizas, superfosfato triplo.

\section{INTRODUCTION}

Brazil has favorable soil and climatic conditions for the cultivation of tropical fruit species and is among the major world producers of fruit and fruit juice. Papaya (Carica papaya L.) is one of the most harvested fruits in the country and its annual production is approximately two billion tons (Agrianual 2011).

One of the limitations in the papaya production chain is the production of high quality seedlings due to the elevated plant density per hectare and the need for orchard renewals every three years. Thus, seedling production is a fundamental step in the implementation of a productive orchard.

Mycorrhized plants exhibit developmental advantages when compared to non-mycorrhized ones under nutrientlimiting conditions. Scientific investigations have shown that inoculation of arbuscular mycorrhizal fungi (AMF) promotes the formation of good quality papaya seedlings (TRINDADE at al. 2001b; MOHANDAS 2012). However, the benefits maximized by that symbiosis in plant nurseries, such as increase in nitrogen (MIYAUCHI at al. 2008), potassium and phosphorus uptake (OLIVEIRA \& OLIVEIRA 2005), tolerance to root diseases (BORGES at al. 2007), and improved seedling growth and vigor during its formation period (LIMA at al. 2011), can be jeopardized under field conditions. Most cultivated areas occur in soils featuring low-fertility, low $\mathrm{pH}$, high aluminum and low phosphorus contents and, consequently, are highly fertilized, primarily with phosphorus, which is an essential nutrient for plant growth and influences root formation and growth, water use efficiency, and uptake and assimilation of other nutrients (Epstein \& Blomm 2006).

Therefore, in phosphorus-rich soils, the advantages of that type of symbiosis are reduced since carbohydrate consumption by the fungi does not cease and, indeed acts as a strong sink. Consequently, the performance of mycorrhized plants can be poorer than that of nonmycorrhized ones (Janos, 2007) which risks seedling survival in the field and causes a decrease in vigor and productivity.

The present research aimed at studying the efficiency of arbuscular mycorrhizal fungi (AMF) on dry matter and nutrient accumulation in Sunrise Solo papaya seedlings, by applying doses of $\mathrm{P}_{2} \mathrm{O}_{5}$ that are detrimental to the symbiosis.

\section{MATERIAL AND METHODS}

The experiment was carried out from January through May 2012 under a shaded environment, at the Department of Plant and Environmental Sciences, Agricultural Sciences Center, Campus II of the Federal University of Paraíba, located in the Municipality of Areia, Paraíba. The climate of the area, classified as As according to the Köppen system, is tropical, hot and humid, exhibiting a rainy season along fall and winter, with an average relative humidity of $80 \%$ (Gondim 1999). During the experiment, the average temperature and relative humidity varied from 22.5 to $23.6^{\circ} \mathrm{C}$ and 60 to $80 \%$, respectively.

The evaluated factors consisted of four $\mathrm{P}_{2} \mathrm{O}_{5}$ doses (0; 672; 1386 and $\left.2100 \mathrm{mg} \mathrm{dm}^{-3}\right)$, based on Melo at al. (2007), and three species of mycorrhizal fungi supplied by Embrapa Agrobiology: Gigaspora margarita, Entrophospora colombiana and Scutellospora heterogama. The control treatment was mycorrhiza- and $\mathrm{P}_{2} \mathrm{O}_{5}$-free. The source of $\mathrm{P}_{2} \mathrm{O}_{5}$ was triple superposphate. The experiment was set up in a randomized block design in the factorial scheme, with four blocks and four seedlings per experimental unit.

Seeds of the cultivar Sunrise Solo, produced by Agristar, were sown in germination trays $(60 \mathrm{~cm} \mathrm{x} 40 \mathrm{~cm})$ containing sand autoclaved at $121{ }^{\circ} \mathrm{C}$. When seedlings reached $5.0 \mathrm{~cm}$ in height they were transferred to $\mathrm{PVC}$ tubes ( $25 \mathrm{~cm}$ length and $8 \mathrm{~cm}$ in diameter) containing 0.7 $\mathrm{dm}^{-3}$ of a substrate mix composed of $75 \%$ soil (Yellow Latosol, total sand $=506 \mathrm{~g} \mathrm{~kg}^{-1}$, silt $=103 \mathrm{~g} \mathrm{~kg}^{-1}$, clay $=391$ $\left.\mathrm{g} \mathrm{kg}^{-1}\right), 15 \%$ sand and $10 \%$ manure. The soil was sandy clay loam and was mixed with cow manure. The mix was passed through a $4 \mathrm{~mm}$ mesh sieve. The physical-chemical characteristics of the mix are shown in Table 1. After autoclaving, $\mathrm{N}, \mathrm{K}, \mathrm{Ca}, \mathrm{Mg}, \mathrm{S}$ and $\mathrm{B}$ were added to the mix, whose amounts were based on its chemical analysis. At transplanting, $3.0 \mathrm{~g}$ of the mix containing fungal spores were added to each tube. Seedlings were irrigated twice a day with chlorine-free water [electrical conductivity - EC $=0.22 \mathrm{dS} . \mathrm{m}^{-1}$ and sodium adsorption rate $-\mathrm{SAR}=2.41$ $\left.\left(\mathrm{mmol}_{\mathrm{c}} \mathrm{L}^{-1}\right)^{0.5}\right]$, in order to keep the substrate under field capacity and avoid excessive water retention. Data collection was carried out 102 days after the beginning of the experiment and the following variables were analyzed: root and shoot dry matter, nitrogen, phosphorus and 
potassium contents of leaves and roots as well as mycorrhizal colonization.

For dry matter and plant tissue analysis, leaves and roots were washed in running water and rinsed with distilled water. Following that, they were placed in paper bags and dried in a drying oven with forced air circulation at $65{ }^{\circ} \mathrm{C}$ until constant weight was reached. After dry matter determination, the plant material was ground in a Willey grinder and then passed through a $0.5 \mathrm{~mm}$ mesh sieve. For nutrient content analysis, the material was digested by use of sulfuric acid $\left(\mathrm{H}_{2} \mathrm{SO}_{4}\right)$ and hydrogen peroxide $\left(\mathrm{H}_{2} \mathrm{O}_{2}\right)$ in a block digester at $350{ }^{\circ} \mathrm{C}$. Nitrogen content was determined through distillation in $13 \mathrm{~N}$ sodium hydroxide $(\mathrm{NaOH})$ followed by titration with $0.07143 \mathrm{~N}$ hydrochloric acid. Phosphorous was quantified by spectrophotometry upon measuring the color intensity of the phosphomolybdic complex, produced as result of the reduction of molybdate with ascorbic acid, and potassium was quantified by the flame photometry method (Embrapa 2011).

Mycorrhizal colonization was assessed by collecting secondary roots of seedlings and immersing them in a sodium hypochlorite solution for 30 seconds followed by another 30 second immersion in $70^{\circ}$ ethyl alcohol. Roots were then rinsed with distilled water, placed in plastic pots containing $50 \mathrm{~mL}$ of $70^{\circ}$ ethyl alcohol and $3.0 \mathrm{~mL}$ of formalin, and kept under refrigeration at $4{ }^{\circ} \mathrm{C}$. For clarification and staining (Phillips \& Hayman 1970) roots were immersed in a $10 \% \mathrm{KOH}$ solution for 15 days at room temperature. After that period, they were washed, acidified in $1 \% \mathrm{HCl}$ for 3 minutes and stained with $1 \mathrm{~mL}$ trypan blue. After 10

Table 1: Physical-chemical characteristics of the substrate mix used for growing papaya seedlings

\begin{tabular}{lcc}
\hline Substrate characteristics & Unit & Value \\
\hline $\mathrm{pH}$ (in water) & - & 6.11 \\
$\mathrm{EC}$ & $\mathrm{dS} \mathrm{m}^{-1}$ & 1.023 \\
$\mathrm{O} . \mathrm{M}$. & $\%$ & 2.4 \\
$\mathrm{~N}$ & $\%$ & 0.14 \\
$\mathrm{P}$ & $\mathrm{mg} \mathrm{dm}^{-3}$ & 3.7 \\
$\mathrm{~K}^{+}$ & $\mathrm{mg} \mathrm{dm}^{-3}$ & 1.23 \\
$\mathrm{Ca}^{+2}$ & $\mathrm{cmol} \mathrm{dm}_{\mathrm{c}} \mathrm{dm}^{-3}$ & 3.6 \\
$\mathrm{Mg}^{+2}$ & $\mathrm{cmol} \mathrm{dm}^{-3}$ & 1.65 \\
Sand & $\%$ & 62 \\
Silt & $\%$ & 12 \\
Clay & $\%$ & 26 \\
Soil density & $\mathrm{kg} \mathrm{dm}^{-3}$ & 1.14 \\
Particle density & $\mathrm{kg} \mathrm{dm}^{-3}$ & 2.6 \\
Porosity & $\mathrm{m}^{3} \mathrm{~m}^{-3}$ & 0.56 \\
\hline
\end{tabular}

EC: electrical conductivity. O.M.: organic matter. O.M.: Humid oxidation with potassium dichromate; $\mathrm{N}$ : sulfuric digestion/ Kjeldahl distillation; P: Mehlich-1 extractor; $\mathrm{K}^{+}$: flame photometry; $\mathrm{Ca}^{+2}$ and $\mathrm{Mg}^{+2}$ : EDTA complexometric titration; Soil texture (sand+silt+Clay): densimeter method; Soil density: volumetric ring system; Particle density: volumetric flask; Porosity: soil density / particle density. minutes, the stained roots were sliced in $1 \mathrm{~cm}$ pieces and uniformly spread in a $1.27 \mathrm{~cm}$ square Pedtri Dish with grid and analyzed in a microscope (each intersection of roots and grid) for the presence or absence of fungal structures (Giovannetti \& Mosse 1980).

Analysis of variance (ANOVA) was used to test the significance of the model sources of variation. The effect of fungal species was compared by the Tukey test and that of triple superphosphate doses by a polynomial regression. The comparison with the control treatment was conducted by the Dunett test. SAS/STAT 9.3 software (SAS 2011) was used for all statistical analyses.

\section{RESULTS AND DISCUSSION}

The results revealed no difference between the mycorrhizal treatments and the control for root dry matter accumulation (Table 2), except for E. colombiana at the lowest phosphate dose, which was $25 \%$ lower when compared to the control. Phosphorous can alter plant growth by allocating large amounts of carbohydrates to increase root biomass. Phosphorus availability also regulates several processes such as phytomass distribution pattern. Fernandes at al. (2000) observed insignificant effects of phosphate fertilization on root dry matter accumulation since the substrate studied already had adequate amounts of phosphorus for seedling growth.

The fact that the control did not differ from the other treatments, in terms of root dry matter accumulation, can be related to the time the seedlings remained in the tubes containing $0.7 \mathrm{dm}^{-3}$ of substrate (102 days), which was long enough for their roots to occupy the entire substrate volume. Trindade at al. (2000), working with the production of papaya seedlings colonized by mycorrhizal fungi, which were grown in plastic bags containing $1 \mathrm{dm}^{-}$ 3 of substrate, also observed that 50 days after transplanting, the roots had spread throughout the whole substrate volume, because it is a fruit species with a high growth index.

The phosphate doses had distinct effects on root and shoot dry matter, depending on the species of fungus inoculated (Figures $1 \mathrm{~A}$ and $\mathrm{B}$, respectively). In the phosphorus-free treatment, $S$. heterogama and $G$. margarita promoted 34 and $24 \%$ increase in root dry matter accumulation, respectively, in comparison with $E$. colombiana (Table 2). Khade at al. (2010), studying the variation in the level of native mycorrhizal colonization in papaya varieties, detected the influence of root colonization on phosphatase activity, which increased as colonization increased.

Regarding E. colombiana, the maximum estimated value of root dry matter $\left(9.03 \mathrm{~g}\right.$ seedling $\left.^{-1}\right)$ was obtained with $1386 \mathrm{mg} \mathrm{dm}^{-3} \mathrm{P}_{2} \mathrm{O}_{5}$ and the responses decreased at 
higher doses (Figure 1A). This behavior can be related to the inhibitory effect of phosphorus on mycorrhizal colonization, as verified with S. heterogama (Figure 2), while the colonization by E. colombiana and G. margarita it was not significantly affected by $\mathrm{P}_{2} \mathrm{O}_{5}$ doses. According Balzergue at al. (2011), elevated phosphorus concentration in the medium is accompanied by a decreased strigolactone content, decreasing the mycorrhizal colonization. Similar results were verified in studies involving mycorrhizal colonization in fruit species, such as Hancornia speciosa (Cardoso Filho at al. 2008) and Citrus species (Nogueira \& Cardoso 2007).

Table 2: Root dry matter (g seedling ${ }^{-1}$ ) of papaya cv. Sunrise Solo seedlings inoculated with mycorrhizal fungi and fertilized with $\mathrm{P}_{2} \mathrm{O}_{5}$

\begin{tabular}{lcccc}
\hline & \multicolumn{4}{c}{ Mycorrhizal fungi } \\
\cline { 2 - 5 } $\mathbf{P}_{2} \mathbf{O}_{\mathbf{5}}\left(\mathbf{m g ~ d m}^{-3}\right)$ & G. margarita & E. colombiana & S. heterogama & Control \\
\hline 0 & $7.34 \mathrm{~ns} \mathrm{~A}$ & $5.88^{*} \mathrm{~B}$ & $7.88 \mathrm{~ns} \mathrm{~A}$ & 7.86 \\
672 & $7.17 \mathrm{~ns} \mathrm{~B}$ & $9.13 \mathrm{~ns} \mathrm{~A}$ & $8.52 \mathrm{~ns} \mathrm{~A}$ & \\
1386 & $8.63 \mathrm{~ns} \mathrm{~A}$ & $8.29 \mathrm{~ns} \mathrm{~A}$ & $7.38 \mathrm{~ns} \mathrm{~A}$ & \\
2100 & $8.35 \mathrm{~ns} \mathrm{~A}$ & $8.06 \mathrm{~ns} \mathrm{~A}$ & $8.41 \mathrm{~ns} \mathrm{~A}$ & \\
\hline
\end{tabular}

Mean values followed by the same block letter within lines are not significantly different according to the Tukey test $(P<0.05)$. ns and *: not significant and significantly different, respectively, from the control treatment, according to the Dunnett's test at $(P<0.05)$; $(P$ $<0.05)$. Control $=$ without fungal inoculation .
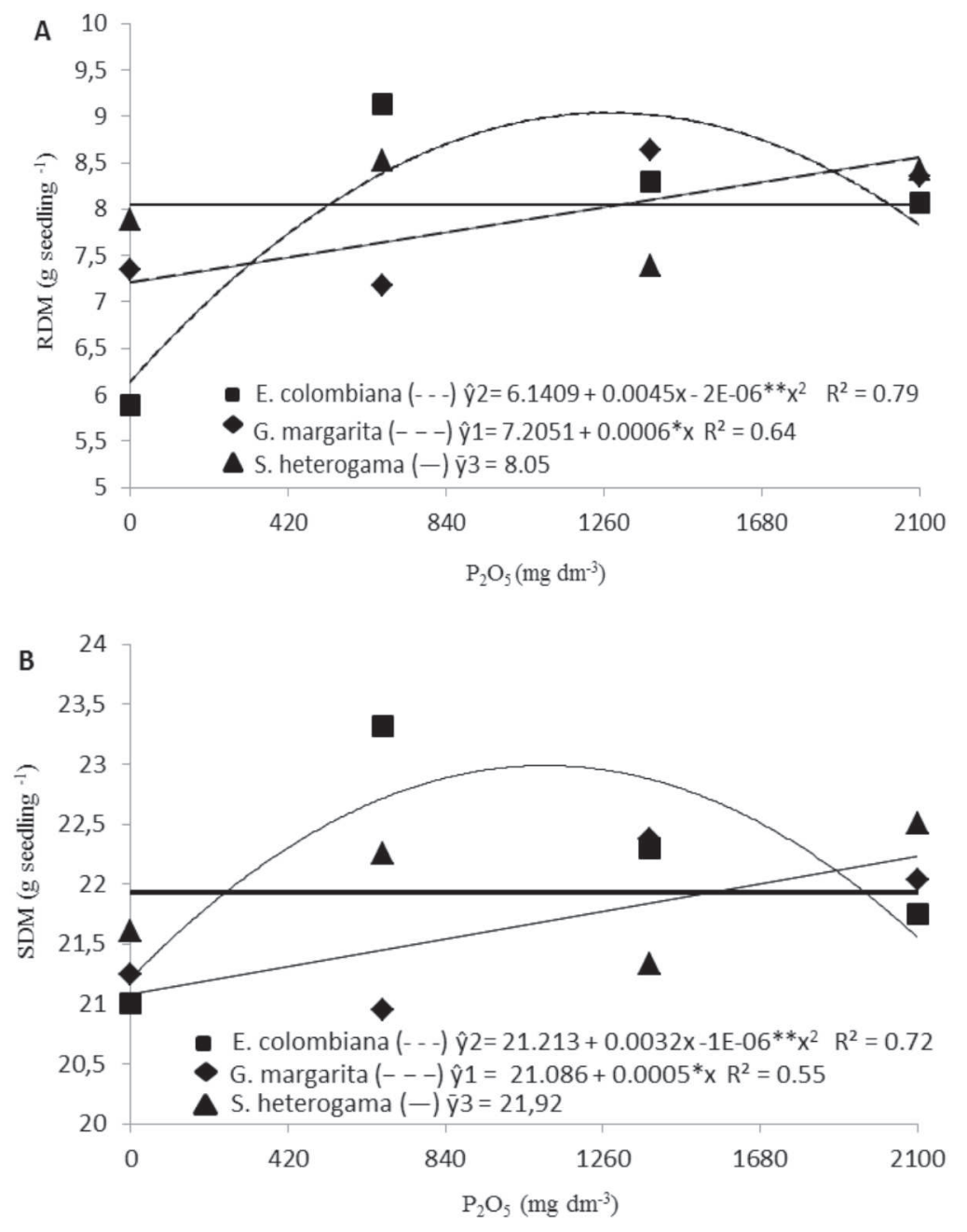

** *: Significant at $(P<0.01)$ and $(P<0.05)$ respectively, according to the $\mathrm{F}$ test.

Figure 1: Root dry matter (RDM) "A" and shoot dry matter (SDM) "B" of papaya cv. Sunrise Solo seedlings inoculated with mycorrhizal fungi and fertilized with $\mathrm{P}_{2} \mathrm{O}_{5}$. 
Inoculation with E. colombiana, G. margarita and $S$. heterogama promoted a 32, 33 and $36 \%$ increase in shoot dry matter, respectively, in relation to the control treatment, but did not differ among the fungal species (Table 3). Lima at al. (2011) reported that papaya seedlings inoculated with mycorrhizal fungi exhibited higher growth rates than those not inoculated, regardless of the amount of phosphorus in the soil.

Shoot dry matter behavior was similar to that observed for root dry matter (Figure $1 \mathrm{~B}$ ). It is worth highlighting the effects on E. colombiana, which exhibited quadratic growth as fertilization doses increased, reaching a maximum value of $22.98 \mathrm{~g}$ seedling $^{-1}$, which corresponds to an estimated dose of $1104 \mathrm{mg} \mathrm{dm}^{-3}$ of $\mathrm{P}_{2} \mathrm{O}_{5}$. This superiority in relation to the control (15.88 $\mathrm{g}$ seedling $\left.{ }^{-1}\right)$ expresses the importance of mycorrhizal fungi in promoting one of the main advantages of that symbiosis: nutrient uptake. The increments in root uptake capacity, provided by hyphae development and branching, which in turn increase root-soil contact area, favor a greater absorption of nutrients such as phosphorus.
Trindade at al. (2001a) demonstrated that papaya cultivars can benefit from inoculation with Glomus clarum and G. margarita, reducing up to seven times the need for $\mathrm{P}$ fertilization so that maximum shoot growth can be achieved. Lima at al. (2011), evaluating growth of papaya cv Golden seedlings, showed that fungal inoculation treatments promoted an increase in seedling leaf area, with an increment of $19.3 \%$ in relation to the control treatment, which influenced dry matter accumulation but did not differ among the fungal species studied.

No differences for leaf $\mathrm{N}$ content of seedlings were detected among mycorrhizal fungi (Table 4). However, all fungi treatments exhibited increases in foliar $\mathrm{N}$, whose values were 24, 23 and $21 \%$ higher than the control for $G$. margarita, E. colombiana and $S$. heterogama, respectively, at $672 \mathrm{mg} \mathrm{dm}^{-3} \mathrm{P}_{2} \mathrm{O}_{5}$ (Table 5). Chu at al. (2001) also reported no differences in terms of foliar N content of Annona muticata seedlings when inoculated with the same fungi species assessed in the present study and using fumigated and nonfumigated soil.

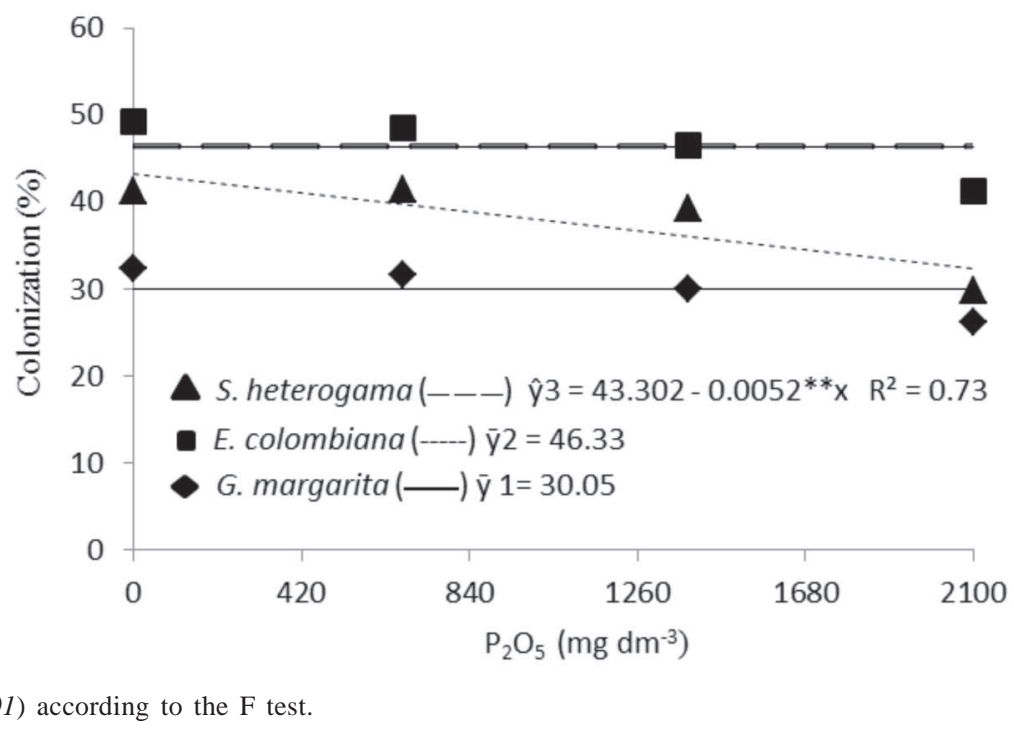

Figure 2: Mycorrhizal colonization in papaya cv. Sunrise Solo seedlings inoculated with mycorrhizal fungi and fertilized with $\mathrm{P}_{2} \mathrm{O}_{5}$.

Table 3: Shoot dry matter (g seedling ${ }^{-1}$ ) of papaya cv. Sunrise Solo seedlings inoculated with mycorrhizal fungi and fertilized with $\mathrm{P}_{2} \mathrm{O}_{5}$

\begin{tabular}{lcccc}
\hline & \multicolumn{4}{c}{ Mycorrhizal fungi } \\
\cline { 2 - 5 } $\mathbf{P}_{2} \mathbf{O}_{\mathbf{5}}\left(\mathbf{m g ~ d m}^{-3}\right)$ & G. margarita & E. colombiana & S. heterogama & Control \\
\hline 0 & $21.24 * \mathrm{~A}$ & $21.00^{*} \mathrm{~A}$ & $21.60 * \mathrm{~A}$ & 15.88 \\
672 & $20.95^{*} \mathrm{~B}$ & $23.31 * \mathrm{~A}$ & $22.25 * \mathrm{~A}$ & \\
1386 & $22.37 * \mathrm{~A}$ & $22.29 * \mathrm{~A}$ & $21.33 * \mathrm{~A}$ & \\
2100 & $22.03 * \mathrm{~A}$ & $21.74 * \mathrm{~A}$ & $22.51 * \mathrm{~A}$ & \\
\hline
\end{tabular}

Mean values followed by the same block letter within lines are not significantly different according to the Tukey test $(P<0.05)$. and *: significantly different, respectively, from the control treatment, according to the Dunnett's test at $(P<0.05) ;(P<0.05)$. Control = without fungal inoculation.

Rev. Ceres, Viçosa, v. 63, n.1, p. 086-094, jan-fev, 2016 
Leaf $\mathrm{N}$ content exhibited a quadratic behavior as $\mathrm{P}_{2} \mathrm{O}_{5}$ doses increased (Figure 3A), reaching a maximum value of $45.38 \mathrm{~g} \mathrm{~kg}^{-1}$ at $336 \mathrm{mg} \mathrm{dm}^{-3} \mathrm{P}_{2} \mathrm{O}_{5}$. Nitrogen uptake by mycorrhizal fungi becomes more efficient because of the small hyphae diameter that penetrate more easily in decomposing organic matter, competing more effectively for recently mineralized $\mathrm{N}$, especially simple nitrogen organic compounds (Hodge, 2003). Contrasting results were reported by Melloni \& Cardoso (1999) in Citrus seedlings. The increasing phosphorus doses favored linear increases in the total amount of macronutrients absorbed by the rootstocks, including nitrogen.

Phosphorus content in the seedlings increased linearly as $\mathrm{P}_{2} \mathrm{O}_{5}$ doses applied to the substrate increased (Figure 3B). Leaf phosphorus content of seedlings inoculated with mycorrhizal fungi also increased in relation to the control treatment at the highest $\mathrm{P}_{2} \mathrm{O}_{5}$ doses. That increase was detected at $\mathrm{P}_{2} \mathrm{O}_{5}$ doses that promoted the highest total phosphorus concentration in the seedlings, with over $80 \%$ increases at $\mathrm{P}_{2} \mathrm{O}_{5}$ doses equal and above $1386 \mathrm{mg} \mathrm{dm}^{-3}$. The positive influence of mycorrhizal inoculation on plant growth is especially associated with the uptake of low mobility nutrients such as phosphorus, copper and zinc, which reach the roots by slow diffusion mechanisms. The fungi can access soluble forms of phosphorus that are also available for non-inoculated plants, but hyphae end up exploring the soil more thoroughly and guarantee better nutrient absorption (Kanno at al. 2006). The increase in leaf phosphorus content as $\mathrm{P}_{2} \mathrm{O}_{5}$ doses increased may not be related to mycorrhizal benefits at higher doses since there is a phosphorus balance between the soil and the plant tissue that controls the symbiotic association (Costa at al. 2001).

The effect of $\mathrm{P}_{2} \mathrm{O}_{5}$ doses on nitrogen and phosphorus content of roots are displayed in Figure 4. Root nitrogen content decreased linearly as $\mathrm{P}_{2} \mathrm{O}_{5}$ doses increased (Figure 4A). However, at lower doses the mycorrhizal effect was more distinct. According to a few authors, mycorrhizal fungi can form associations with nitrogen-fixing bacteria. The fungus plays a central role in providing phosphorus for the plant and for the bacteria in the nodules, a process that is ATP-dependent (Barea at al. 1992). Nitrogen

Table 4: Nutrient content $\left(\mathrm{g} \mathrm{kg}^{-1}\right)$ in roots and leaves of papaya cv. Sunrise Solo seedlings inoculated with mycorrhizal fungi

\begin{tabular}{|c|c|c|c|c|c|c|}
\hline & \multicolumn{3}{|c|}{ Leaf content } & \multicolumn{3}{|c|}{ Root content } \\
\hline & $\mathbf{N}$ & $\mathbf{P}$ & $\mathbf{K}$ & $\mathbf{N}$ & $\mathbf{P}$ & $\mathbf{K}$ \\
\hline & \multicolumn{6}{|c|}{$\left(\mathrm{g} \mathrm{kg}^{-1}\right)$} \\
\hline Gigaspora margarita & $43.35 \mathrm{a}$ & $8.05 \mathrm{a}$ & $44.66 \mathrm{a}$ & $11.08 \mathrm{a}$ & $10.07 \mathrm{a}$ & $30.23 \mathrm{a}$ \\
\hline Entrophospora colombiana & $43.99 \mathrm{a}$ & $7.94 \mathrm{a}$ & $43.08 \mathrm{ab}$ & $10.78 \mathrm{a}$ & $8.74 \mathrm{a}$ & $27.22 \mathrm{a}$ \\
\hline Scutellospora heterogama & $43.9 \mathrm{a}$ & $7.73 \mathrm{a}$ & $39.92 \mathrm{~b}$ & $10.51 \mathrm{a}$ & $9.27 \mathrm{a}$ & $26.79 \mathrm{a}$ \\
\hline
\end{tabular}

Mean values followed by the same letter within columns are not significantly different according to the Tukey test $(P<0.05)$

Table 5: Nutrient content $\left(\mathrm{g} \mathrm{kg}^{-1}\right)$ in roots and leaves of papaya cv. Sunrise Solo seedlings inoculated with mycorrhizal fungi and fertilized with $\mathrm{P}_{2} \mathrm{O}_{5}$

\begin{tabular}{|c|c|c|c|c|c|c|c|}
\hline \multirow{3}{*}{$P_{2} O_{5}\left(\mathrm{mg} \mathrm{dm}^{-3}\right)$} & \multirow{3}{*}{ Fungus } & \multicolumn{2}{|c|}{$\mathbf{N}$} & \multicolumn{2}{|c|}{$\mathbf{P}$} & \multicolumn{2}{|c|}{$\mathbf{K}$} \\
\hline & & Roots & Leaves & Roots & Leaves & Roots & Leaves \\
\hline & & \multicolumn{6}{|c|}{$\left(\mathrm{g} \mathrm{kg}^{-1}\right)$} \\
\hline \multirow[t]{3}{*}{0} & G. margarita & $11.66^{*}$ & $44.13 \mathrm{~ns}$ & $5.52 \mathrm{~ns}$ & $5.56 \mathrm{~ns}$ & $29.04 \mathrm{~ns}$ & $44.4 \mathrm{~ns}$ \\
\hline & E. colombiana & $11.2^{*}$ & $44.96^{*}$ & $4.41 \mathrm{~ns}$ & $5.24 \mathrm{~ns}$ & $26.41 \mathrm{~ns}$ & $43.34 \mathrm{~ns}$ \\
\hline & S. heterogama & $11.66^{*}$ & $45.4 *$ & $5.61 \mathrm{~ns}$ & $5.51 \mathrm{~ns}$ & $25.88 \mathrm{~ns}$ & $39.13 \mathrm{~ns}$ \\
\hline \multirow[t]{3}{*}{672} & G. margarita & $10.96 \mathrm{~ns}$ & $46.93 *$ & $9.39 *$ & $7.81^{*}$ & $31.68 \mathrm{~ns}$ & $43.34 \mathrm{~ns}$ \\
\hline & E. colombiana & $11.4^{*}$ & $46.36^{*}$ & $7.54 *$ & $7.47 *$ & $26.41 \mathrm{~ns}$ & $45.45 \mathrm{~ns}$ \\
\hline & S. heterogama & $11.05 *$ & $45.46^{*}$ & $8.55^{*}$ & $6.85 \mathrm{~ns}$ & $25.36 \mathrm{~ns}$ & $40.18 \mathrm{~ns}$ \\
\hline \multirow[t]{3}{*}{1386} & G. margarita & $10.9 \mathrm{~ns}$ & $41.96 \mathrm{~ns}$ & $12.24 *$ & $9.08 *$ & $30.62 \mathrm{~ns}$ & $45.45 \mathrm{~ns}$ \\
\hline & E. colombiana & $10.25 \mathrm{~ns}$ & $42.83 \mathrm{~ns}$ & $10.59^{*}$ & $8.67 *$ & $28.52 \mathrm{~ns}$ & $41.24 \mathrm{~ns}$ \\
\hline & S. heterogama & $9.43 \mathrm{~ns}$ & $43.53 \mathrm{~ns}$ & $11.19^{*}$ & $8.83^{*}$ & $30.89 \mathrm{~ns}$ & $40.18 \mathrm{~ns}$ \\
\hline \multirow[t]{4}{*}{2100} & G. margarita & $10.8 \mathrm{~ns}$ & $40.36 \mathrm{~ns}$ & $13.13^{*}$ & $9.75 *$ & $29.57 \mathrm{~ns}$ & $45.45 \mathrm{~ns}$ \\
\hline & E. colombiana & $10.1 \mathrm{~ns}$ & $41.8 \mathrm{~ns}$ & $13.02 *$ & $10.36^{*}$ & $27.99 \mathrm{~ns}$ & $42.19 \mathrm{~ns}$ \\
\hline & S. heterogama & $9.8 \mathrm{~ns}$ & $41.2 \mathrm{~ns}$ & $12.93^{*}$ & $9.72 *$ & $26.41 \mathrm{~ns}$ & $40.18 \mathrm{~ns}$ \\
\hline & CONTROL & 8.8 & 37.55 & 2.82 & 4.77 & 28.52 & 41.24 \\
\hline
\end{tabular}

$\mathrm{ns}$ and $*$ : not significant and significantly different at $(P<0.05)$, respectively, in relation to the control treatment according to the Dunnett's test $(P<0.05)$. Control $=$ without fungal inoculation and fertilization. 
fertilization may positively or negatively interfere with the development of plant mycorrhizal dependency. Santos at al. (2001) observed a decrease in the number of spores as nitrogen fertilization increased.

Root phosphorus content exhibited a quadratic tendency in response to an increase in the amount of that nutrient in the substrate (Figure 4B). Based on the studies conducted by Moreira \& Siqueira (2002), it can be assumed that in conditions of high phosphorus supply, phospholipid biosynthesis is increased, and as a result, cell permeability is affected. Thus, root exudation (sugars and amino acids), infection and colonization decline, as proved by colonization of $S$. heterogama (Figure 4B). The data revealed a higher phosphorus content in the tissues of inoculated seedlings in relation to the control (Table 5), reaching the highest value $\left(12.3 \mathrm{~g} \mathrm{~kg}^{-1}\right)$ at $1978 \mathrm{mg} \mathrm{dm}^{-3}$ $\mathrm{P}_{2} \mathrm{O}_{5}$ (Figure 4B); these results were more evident than those reported by Trindade at al. (2001b). This can be due to the high doses used in the present study. Differences were only detected at doses equal or higher than $672 \mathrm{mg} \mathrm{dm}^{-3} \mathrm{P}_{2} \mathrm{O}_{5}$. Increments of 201, 302 and $361 \%$ were verified at 672,1386 and $2100 \mathrm{mg} \mathrm{dm}^{-3} \mathrm{P}_{2} \mathrm{O}_{5}$, respectively, when comparing fungi treatments with the control. No difference was detected among the fungi used (Table 4).

The increase in phosphorus content of roots and leaves is a result of a higher amount of $\mathrm{P}_{2} \mathrm{O}_{5}$ in the substrate. As it is a highly mobile nutrient, its concentration was higher in the tissues of those two organs. Mesquita at al. (2010), studying leaf mineral composition of papaya fertilized with an enriched biofertilizer, detected phosphorus increments of $4.2 \mathrm{~g} \mathrm{~kg}^{-1}$, which were inferior to the results obtained in the present study.

Production of quality papaya seedlings, aiming at the enhancement of their performance after transfer to the field, makes the potential use of AMF more attractive since it is responsible for increasing the efficiency of nutrient uptake, thus reducing the use of fertilizers without affecting productivity.
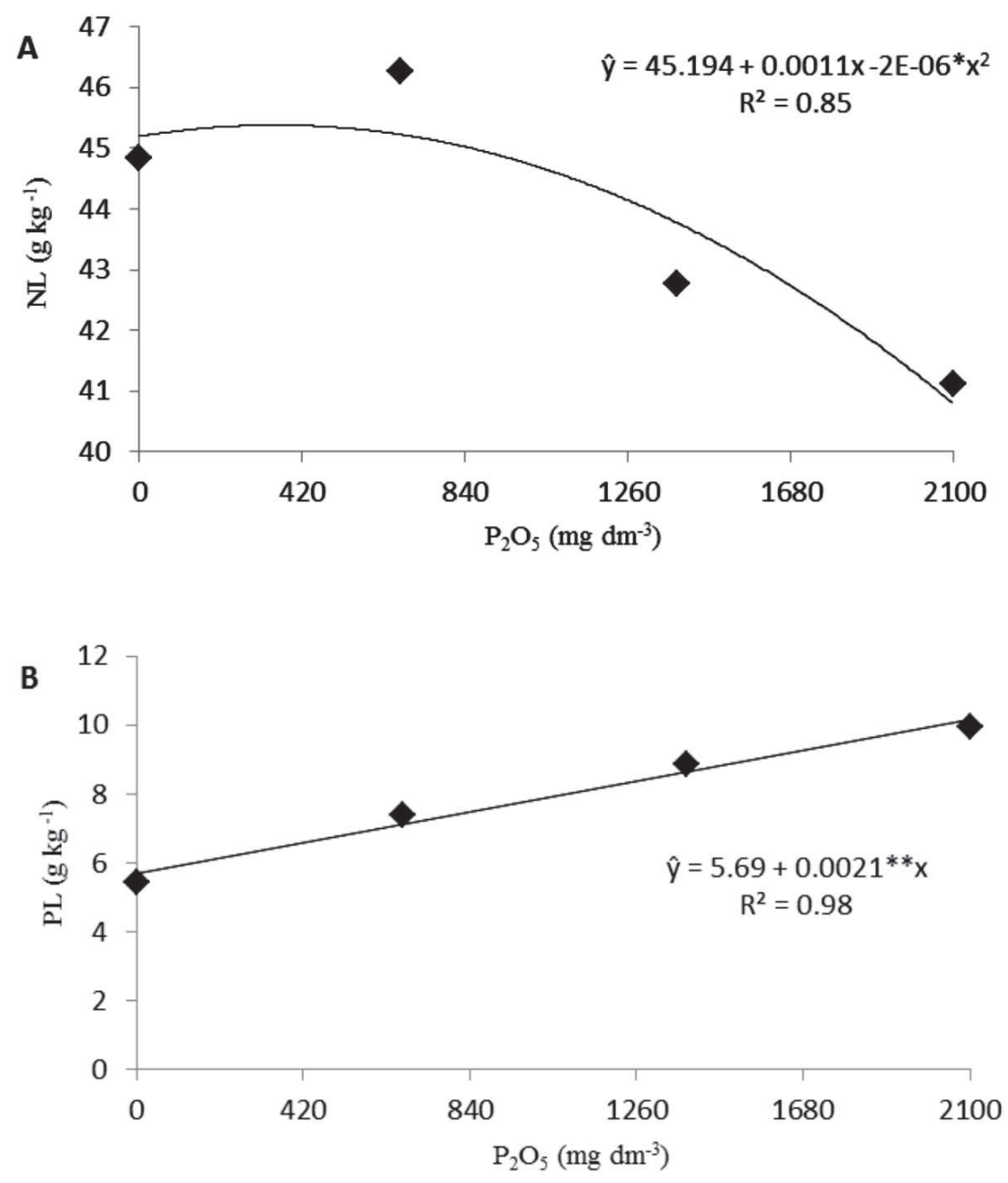

** *: Significant at $(P<0.01)$ and $(P<0.05)$ respectively, according to the $\mathrm{F}$ test

Figure 3: Nitrogen (NL) "A" and phosphorus (PL) "B" contents in leaves of papaya cv. Sunrise Solo seedlings inoculated with mycorrhizal fungi and fertilized with $\mathrm{P}_{2} \mathrm{O}_{5}$. 

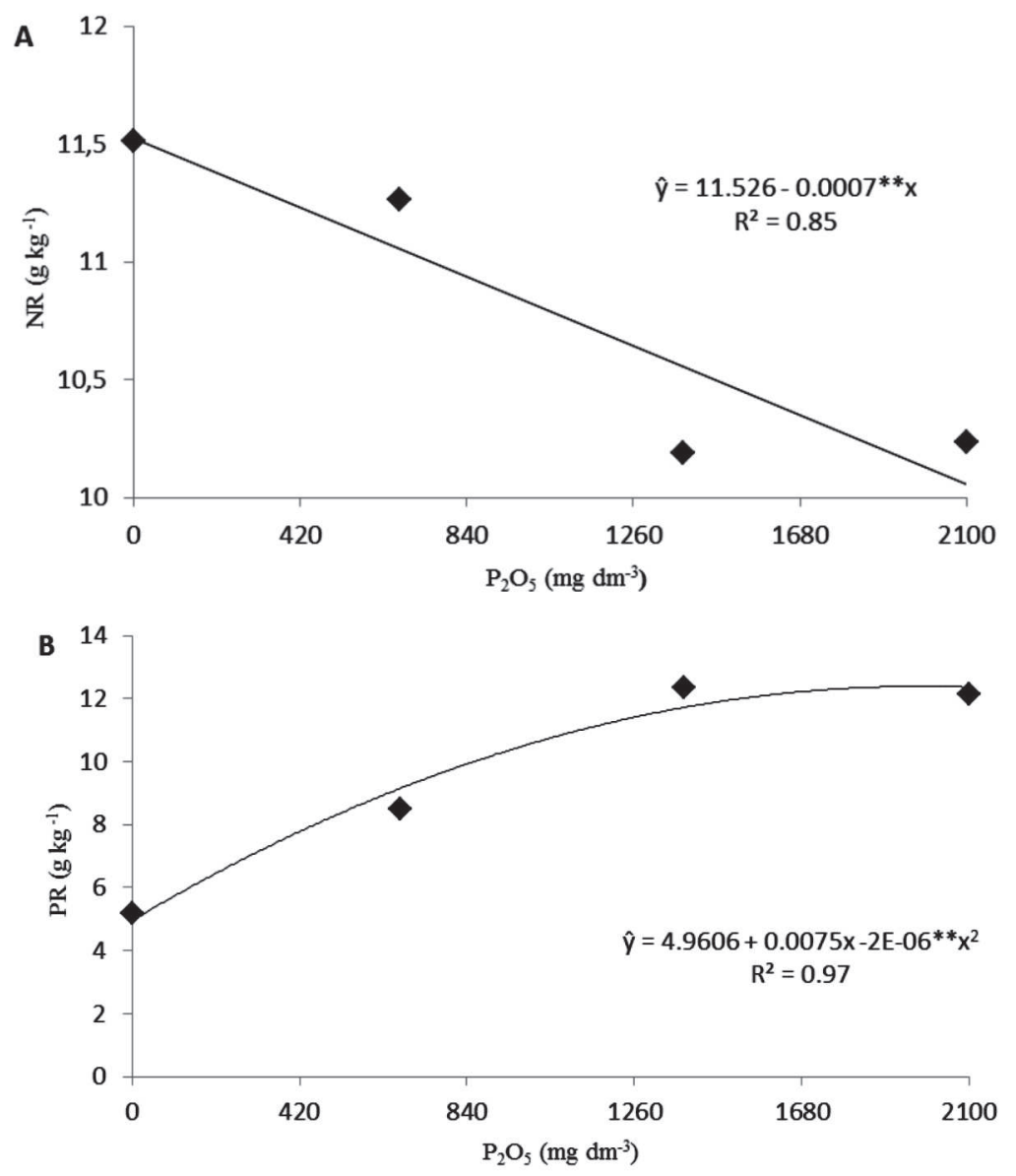

**: Significant at $(P<0.01)$ according to the $\mathrm{F}$ test

Figure 4: Nitrogen (NR) "A" and phosphorus (PR) "B" contents in roots of papaya cv. Sunrise Solo seedlings inoculated with mycorrhizal fungi and fertilized with $\mathrm{P}_{2} \mathrm{O}_{5}$.

\section{CONCLUSION}

Mycorrhizal inoculation reduced the need for additional phosphorus fertilization in papaya seedlings, since it promoted increases of over $30 \%$ in shoot dry matter in relation to the control.

E. colombiana favored the highest gains in root and shoot dry matter, but became a sink at $\mathrm{P}_{2} \mathrm{O}_{5}$ doses above $1386 \mathrm{mg} \mathrm{dm}^{-3}$.

The mycorrhizal fungi promoted increases in foliar and root nitrogen content up to $672 \mathrm{mg} \mathrm{dm}^{-3} \mathrm{P}_{2} \mathrm{O}_{5}$ and were tolerant to amounts considered harmful to the symbiosis.

\section{REFERENCES}

Agrianual (2011) Anuário da agricultura brasileira. São Paulo, FNP. p.325-332.

Barea JM, Azcón R \& Azcón-Aguilar C (1992) Vesicular-arbuscular mycorrhizal fungi in nitrogen-fixing systems. In: Norris JR, Read DJ \& Varma AK (Eds.) Methods in microbiology. Academic Press, London. p.391-416.
Balzergue C, Puech-Pagés V, Bécard G, Rochange SF (2011) The regulation of arbuscular mycorrhizal symbiosis by phosphate in pea involves early and systemic signalling events. Journal of Experimental Botany, 62:1049-1060.

Borges AJS, Trindade AV, Matos AP \& Peixoto MFS (2007) Redução do mal-do-panamá em bananeira-maçã por inoculação de fungo micorrízico arbuscular. Pesquisa Agropecuária Brasileira, 42:35-41.

Cardoso Filho JA, Lemos EEP, Santos TMC, Caetano LC \& Nogueira MA (2008) Mycorrhizal dependency of mangaba tree under increasing phosphorus levels. Pesquisa Agropecuária Brasileira, 43:887-892.

Chu EY, Möller MRF \& Carvalho JG (2001) Efeitos da inoculação micorrízica em mudas de gravioleira em solo fumigado e não fumigado. Pesquisa Agropecuária Brasileira, 36:671-680.

Costa CMC, Maia LC \& Cavalcante UMT (2001) Influência de fungos micorrízicos arbusculares sobre o crescimento de dois genótipos de aceroleira (Malpighia emarginata D.C.). Pesquisa Agropecuária Brasileira, 36:893-901.

EMBRAPA - Empresa Brasileira de Pesquisa Agropecuária (2011) Manual de métodos de análises de solos. $3^{\mathrm{a}}$ ed. Rio de Janeiro, Embrapa Solos. 230p.

Epstein E \& Bloom AJ (2006) Nutrição mineral de plantas: princípios e perspectivas. PLANTA, Londrina. 403p. 
Fernandes LA, Futini Neto AE, Fonseca FC \& Vale FR (2000) Crescimento inicial, níveis críticos de fósforo e fração fosfatada em espécies florestais. Pesquisa Agropecuária Brasileira, 35:1191-1198.

Giovannetti M \& Mosse B (1980) An evaluation of techniques for measuring vesicular-arbuscular mycorrhizal infection on roots. New Phytologist, 84:489-500.

Gondim AWA (1999) Geoeconomia e agricultura do brejo paraibano: análise e avaliação. João Pessoa, UFPB. 206p.

Hodge A (2003) Plant nitrogen capture from organic matter as affected by spatial dispersion, interspecific competition and mycorrhizal colonization. New Phytologist, 157:303-314.

Janos DP (2007) Plant responsiveness to mycorrhizas differs from dependence upon mycorrhizas. Mycorrhiza, 17:75-91.

Kanno T, Saito M, Ando Y, Macedo MCM, Nakamura T \& Miranda CHB (2006) Importance of indigenous arbuscular mycorrhiza for growth and phosphourus uptake in tropical forage grasses growing on an acid soil, infertile soil from the Brazilian savannas. Tropical Grasslands, 40:94-10.

Khade SW, Rodrigues BF \& Sharma PK (2010) Arbuscular mycorrhizal status and root phosphatase activities in vegetative Carica papaya L. varieties. Acta Physiologiae Plantarum, 32:565-574.

Lima KB, Martins MA, Freitas MSM \& Olivares FL (2011) Fungos micorrízicos arbusculares, bactérias diazotróficas e adubação fosfatada em mudas de mamoeiro. Revista Brasileira de Fruticultura, 33:932-940.

Melloni R \& Cardoso EJBN (1999) Quantificação de micélio extrarradicular de fungos micorrízicos arbusculares em plantas cítricas. II. Comparação entre diferentes espécies cítricas e endófitos. Revista Brasileira de Ciência do Solo, 23:59-67.

Melo AS, Costa CX, Brito MEB, Viégas PRA \& Silva Júnior CD (2007) Produção de mudas de mamoeiro em diferentes substratos e doses de fósforo. Revista Brasileira de Ciências Agrárias, 2:257261 .

Mesquita EF, Cavalcante LF, Gondim SC, Campos VB, Cavalcante IHL \& Gondim PC (2010) Teores foliares e exportação de nutrientes do mamoeiro 'Baixinho de Santa Amália' tratado com biofertilizantes. Pesquisa Agropecuária Tropical, 40:6676.
Miyauchi MYH, Lima DS, Nogueira MA, Lovato GM, Murate LS, Cruz MF, Ferreira JM, Zangaro W \& Andrade G (2008) Interactions between diazotrophic bacteria and mycorrhizal fungus in maize genotypes. Scientia Agricola, 65:525-531.

Mohandas S (2012) Field response of papaya (Carica papaya L. cv. Coorg Honey Dew) to inoculation with arbuscular mycorrhizal fungi at different levels of phosphorus. Journal of Horticultural Science and Biotechnology, 87:514-518.

Moreira FMS \& Siqueira JO (2002) Microbiologia e bioquímica do solo. Lavras, Universidade Federal de Lavras. 625p.

Nogueira MA \& Cardoso EJBN (2007) Phosphorus availability changes the internal and external endomycorrhizal colonization and effects symbiotic effectiveness. Scientia Agricola, 64:295300 .

Oliveira NA \& Oliveira LA (2005) Colonização por fungos micorrizicos arbusculares e teores de nutrientes em cinco cultivares de bananeiras em um latossolo da Amazônia. Revista Brasileira de Ciência do Solo, 29:481-488.

Phillips JM \& Hayman DS (1970) Improved procedures for cleaning roots and staining parasitic and vesicular-arbuscular mycorrhizal fungi for rapid assessment of infection. Transactions of the British Mycological Society, 55:158-160.

Santos IPA, Pinto JC, Siqueira JO, Morais AR, Curi N \& Evangelista AR (2001) Resposta a fósforo, micorriza e nitrogênio de braquiarão e amendoim forrageiro consorciados. 1- Rendimento de matéria seca da parte aérea e da raiz. Ciências Agrotécnicas, 25:1206-1215.

SAS Institute Inc. (2011) Statistical Analysis System user's guide. Version 9.3. Cary, Statistical Analysis System Institute. 513p.

Trindade AV, Siqueira JO \& Almeida FP (2001a) Dependência micorrízica de variedades comerciais de mamoeiro. Pesquisa Agropecuária Brasileira, 36:1485-1494.

Trindade AV, Dantas JLL, Almeida FP \& Maia ICS (2001b) Estimativa do coeficiente de determinação genotípica em mamoeiros (Carica papaya L.) inoculados com fungo micorrízico arbuscular. Revista Brasileira de Fruticultura, 23:607-612.

Trindade AV, Farias NG \& Almeida FP (2000) Uso de esterco no desenvolvimento de mudas de mamoeiro colonizadas com fungos micorrízicos. Pesquisa Agropecuária Brasileira, 35:13891394. 